\title{
PENGARUH PENGAJARAN PEMROGAMAN ANIMASI MELALUI APLIKASI SCRATCH PADA KEMAMPUAN PEMECAHAN MASALAH
}

\author{
Afis Pratama \\ IKIP Veteran Jawa Tengah \\ afistama@gmail.com
}

Disetujui: April 2018. Dipublikasikan: April 2018

\begin{abstract}
ABSTRAK
Pemrograman Animasi komputer dianggap sebagai kompetensi penting bagi pengembangan keterampilan pemecahan masalah selain penalaran logis. Oleh karena itu, integrasinya di semua tingkat pendidikan, dan juga usia dini, dianggap penting dan studi penelitian dilakukan untuk mengeksplorasi fenomena tersebut secara lebih rinci. Mengingat fakta ini, penelitian ini merupakan upaya eksplorasi untuk menyelidiki pengaruh pemrograman Scratch pada keterampilan pemecahan masalah mahasiswa Pendidikan Informatika. Penelitian ini dilakukan dengan desain metode gabungan kuantitatif dan kualitatif pada 21 orang mahasiswa. Menurut hasil kuantitatif, pemrograman di platform Scratch tidak menyebabkan perbedaan yang signifikan dalam keterampilan memecahkan masalah mahasiswa sekolah dasar. Hanya ada peningkatan yang tidak signifikan dalam mean faktor "kepercayaan diri terhadap kemampuan pemecahan masalah mereka". Ketika pemikiran mahasiswa dipertimbangkan, dapat dikatakan dengan jelas bahwa semua mahasiswa menyukai pemrograman dan ingin memperbaiki program mereka. Akhirnya, sebagian besar mahasiswa menemukan platform Scratch mudah digunakan.
\end{abstract}

Kata Kunci: Pemrogaman Animasi, Scratch, Kemampuan Pemecahan Masalah

\begin{abstract}
Computer Animation Programming is considered an essential competency for the development of problem solving skills other than logical reasoning. Therefore, its integration at all levels of education, as well as early age, is considered important and research studies are undertaken to explore the phenomenon in greater detail. In light of this fact, this research is an exploration effort to investigate the effect of Scratch programming on student problem solving skills of Informatics Education. This research was conducted with the design of quantitative and qualitative methods combined in 21 students. According to quantitative results, programming on the Scratch platform does not cause a significant difference in the problem-solving skills of elementary school students. There is only an insignificant increase in the mean factor of "confidence in their problem-solving ability". When student thinking is considered, it is clear that all students love programming and want to improve their program. Finally, most students found the Scratch platform easy to use.
\end{abstract}

Keywords: Animation Programming, Scratch, Problem Solving Skill.

\section{PENDAHULUAN}

Game merupakan suatu hal yang menarik untuk dimainkan oleh hampir semua kalangan. Di dalam game terdapat animasianimasi yang menarik sehingga dapat menimbulkan rasa ketertarikan penggunanya. Masyarakat Indonesia khususnya dalam 12 tahun terakhir, pengguna game online telah mengalami kemajuan yang sangat pesat (tribunnews.com). Perkembangan ini terlihat dari banyaknya pusat game di kota-kota besar maupun kecil. Mata kuliah Animasi adalah mata kuliah yang mempelajari urutan atau langkah-langkah untuk membuat atau menyelesaikan masalah animasi melalui 
pemrogaman komputer. Terdapat masalah dalam pelaksanaan perkuliahan Animasi di IKIP Veteran Semarang, mahasiswa sering kali merasa malas dalam mempelajari mata kuliah ini. Hal ini dikarenakan kesan yang beredar bahwa mata kuliah animasi sulit untuk dipelajari. Upaya untuk menyelesaikan masalah ini adalah dengan mengajarkan mahasiswa tentang pemrogaman berbasis scratch. Melalui program scratch mahasiswa akan diajarkan untuk membuat sebuah game sederhana yang bertujuan untuk membangkitkan minat belajar dan mengubah persepsi mahasiswa tentang mata kuliah Animasi.

\section{Scratch}

Fokus Scratch adalah membuat produk multimedia, dan membagikannya di komunitas online besar dan aktif yang dipandu oleh situs web proyek. Hal ini dimaksudkan untuk memungkinkan dan mengembangkan kreativitas anak, tapi juga mengenalkannya pada pemrograman, dengan cara yang menyenangkan.

\section{Visual Programming}

Cara program yang ditulis dalam Scratch adalah dengan memasang "blok," sama seperti kepingan Lego; atau potongan teka-teki gambar. Dalam hal ini, bahasa pemrograman dalam Scratch adalah "bahasa visual", (Green \& Petre, 1996). Blok hanya bisa sesuai dengan cara yang masuk akal, karena bentuknya, jadi tidak mungkin mendapatkan pesan kesalahan dari kompilator. Ini sangat melegakan untuk pemrograman pengantar, dan menghemat pelajar dari sebagian besar sakit hati yang secara tradisional dipaksakan pada mereka dengan bahasa tekstual. Peserta didik dalam Scratch tidak diintimidasi oleh kompilator saat mereka melupakan titik koma atau memiliki tanda kurung yang tidak sesuai, karena kesalahan tersebut tidak mungkin dilakukan. Sejauh pemula menjadi frustrasi atau gentar akibat banjir kesalahan kompilator, bahasa visual di Scratch memberi daya tarik yang kuat untuk tujuan pendidikan.

\section{Scrtach untuk Programmer Pemula}

Sistem Scratch telah menjadi tren baik dengan pengguna yang dimaksud, di lingkungan clubhouse komputer, seperti yang dilaporkan oleh pengembang (Maloney et al., 2008). Anak-anak menghabiskan lebih banyak waktu mengerjakan Scratch daripada dengan paket lain yang tersedia bagi mereka. Tampak jelas bahwa Scratch berhasil dalam menumbuhkan kreativitas dan berbagi produk multimedia dengan baik.

Diperkirakan sejak awal bahwa sementara proyek ini adalah untuk mengenalkan komputer ke wilayah yang berbeda, manfaat pendidikan akan diteliti di kemudian hari (Resnick, Kafai, \& Maeda, 2003). Karena Scratch adalah sistem baru, hanya ada beberapa studi tentang penggunaannya dalam pemrograman pengajaran sejauh ini.

Dalam sebuah penelitian, Scratch digunakan di universitas Harvard (Malan \& Leitner, 2007), di mana ia digunakan untuk mengenalkan para pemula ke pemrograman sebelum transisi mereka ke Jawa. Ada persetujuan hampir total Scratch di antara peserta didik yang merupakan murid sejati; dan satu-satunya peserta didik yang tidak setuju bahwa hal itu berguna bagi mereka adalah sedikit orang yang sudah memiliki pengalaman pemrograman.

Studi percontohan lainnya dilakukan di Amerika Serikat dengan anak perempuan kelas 8 di sekolah menengah, di mana tujuannya adalah untuk melihat apakah murid-murid itu akan belajar menghargai dasar-dasar pemrograman dalam rentang 
lokakarya tiga jam (Sivilotti \& Laugel, 2008). Gadis-gadis itu bukan murid yang lengkap, semua telah menggunakan Scratch atau Lego Mindstorms atau Logo sebelumnya. Mereka melaporkan bahwa mereka telah mengetahui sesuatu yang berharga dan betapa menyenangkannya mereka (rata-rata 3 dan 3,4 masing-masing, dalam skala 4 poin).

\section{METODE}

\section{Desain Penelitian}

Penelitian ini dilakukan dengan metode kuantitatif dan kualitatif. (Tabel 1). Dalam perancangan penelitian ini, peneliti mengumpulkan data kuantitatif dan kualitatif secara berurutan. "Alasan untuk pendekatan ini adalah bahwa data kuantitatif dan hasil memberikan gambaran umum tentang masalah penelitian. Selanjutnya akan dilakukan analisis lebih, khususnya melalui pengumpulan data kualitatif, diperlukan untuk memperbaiki, memperluas, atau menjelaskan gambaran umum" (Creswell, 2012, hal 542).

Bagian kuantitatif dilakukan pada desain kuasi eksperimental pre-test dan posttest. Variabel perlakuan dalam penelitian ini adalah Pemrogaman Scratch. Variabel dependen dari penelitian ini adalah kemampuan memecahkan masalah. Nilai keterampilan pemecahan masalah dikumpulkan melalui Problem Solving Inventory (PSI). Pada bagian kualitatif penelitian, mahasiswa diamati oleh seorang pengamat independen dengan formulir pengamatan saat mereka memprogram. Setelah proses eksperimen lima minggu, wawancara kelompok terarah dilakukan dengan mahasiswa tentang proses eksperimental dengan kuesioner wawancara terstruktur. Penelitian ini menggunakan 21 orang mahasiswa Pendidikan Informatika
IKIP Veteran Jawa Tengah sebagai pastisipan.

Tabel 1. Desain Penelitian

\begin{tabular}{llcl}
\hline Classe & Pre-test & Perlakuan (4 Minggu) & Post-test \\
\hline $5-\mathrm{A}$ & PSI & $\mathrm{T}$ & PSI \\
$5-\mathrm{B}$ & PSI & $\mathrm{T}$ & PSI \\
$5-\mathrm{C}$ & PSI & $\mathrm{T}$ & PSI \\
\hline
\end{tabular}

\section{Proses}

Proses eksperimental dimulai dengan penerapan PSI kepada mahasiswa sebagai pre-test. Kemudian mahasiswa diajarkan topik seperti pengenalan pemrograman Scratch, pemasangan platform Scratch, pengenalan user interface dan penulisan program secara terpisah seperti program Hello World, Parrot, Aquarium dan proyek Maze. Secara total, para mahasiswa telah menghabiskan waktu lima jam untuk menulis program ini di kelas.

Dalam program Hello World, berbeda dengan program Hello World klasik, mahasiswa menambahkan gambar latar belakang ke adegan mereka. Kemudian mereka menugaskan perintah suara meong ke karakter kucing, mereka memindahkan kucing itu dan akhirnya mereka membuat kucing itu memberi pesan seperti "Selamat Datang", dan "Hari ini kita akan belajar Scratch". Dalam program Parrot, mahasiswa belajar bagaimana memulai program, mengulangi blok dan mengubah karakter kucing. Mereka membuat karakter Parrot terbang dengan mengganti kostumnya. Rangkaian kegiatan tertulis dalam Tabel 2. 
Tabel 2. Rangkaian Kegiatan Pelatihan Scratch

\begin{tabular}{cl}
\hline No. & \multicolumn{1}{c}{ Aktivitas } \\
\hline 1 & Introduction to Scratch programming \\
2 & Installation of Scratch platform \\
3 & Introduction to User Interface \\
4 & Hello World program \\
5 & Working with blocks \\
6 & Parrot program \\
7 & Working with blocks \\
8 & Aquarium program \\
9 & Operators and Variables \\
10 & Maze program \\
11 & Random Number and Jazz programs \\
12 & What is your Name? program \\
13 & Guess program \\
\hline
\end{tabular}

\section{Teknik Pengumpulan Data}

\section{Kuantitatif}

Sebagai ukuran kuantitatif, Soal Pemecahan Masalah Serin, Bulut Serin, dan Saygılı (2010) digunakan dalam penelitian ini. Alat ukur ini dapat digunakan untuk mengetahui tingkat persepsi diri mahasiswa sekolah dasar tentang keterampilan pemecahan masalah mereka. Setelah pelaksanaan inventarisasi kepada 20 mahasiswa dari kelas yang berbeda $(4,5,6$, 7, dan 8) dan setelah analisis faktor, koefisien Alpha Cronbach ditemukan 0,80. Dalam inventarisasi ini, ada 24 item dengan tiga faktor, 12 item untuk kepercayaan diri terhadap kemampuan pemecahan masalah mereka, 7 item untuk pengendalian diri dan 5 item untuk menghindari atau pengelakan.

\section{Kualitatif}

Setelah menyelesaikan program dan pelaksanaan inventarisasi, guru memilih empat atau lima mahasiswa dari masing- masing kelas sesuai minat dan kesuksesan mereka dalam pemrograman Gores. Salah satu peneliti melakukan wawancara kelompok terarah dengan formulir wawancara terstruktur. Pendapat ahli tentang pertanyaan yang digunakan dalam formulir wawancara diambil. Menurut pendapat ahli, ungkapan satu item dikoreksi dan urutan yang lain telah diubah. Pertanyaan di bawah ini diajukan kepada para mahasiswa:

a. Apakah Anda mengalami kesulitan dengan proses pemecahan masalah?

b. Bisakah Anda memecahkan masalah dengan cara yang berbeda? Atau bisakah Anda mencoba memecahkannya?

c. Apa aspek favorit Anda dari aplikasi ini?

d. Apa aspek favorit Anda dari aplikasi ini?

e. Apakah penggunaan platform itu mudah? Apakah Anda menghadapi masalah dalam platform?

f. Apakah kamu suka animasi pemrograman?

g. Apa yang ingin Anda pelajari lebih lanjut tentang pemrograman?

h. Apakah Anda ingin memperbaiki diri?

Sementara mahasiswa melakukan tugas mereka, seorang dosen mengamati mahasiswa sesuai dengan daftar item yang diberikan oleh para peneliti. Pendapat ahli tentang barang dalam bentuk observasi juga diambil. Item diberi nilai $0,1,2$ atau 'tidak sesuai'. Item di bawah ini digunakan untuk mengamati setiap mahasiswa di kelas:

a. Mahasiswa memahami programnya.

b. Mahasiswa menyarankan cara yang berbeda untuk menulis program.

c. Solusi yang diajukan mahasiswa sering memberikan hasil yang benar.

d. Mahasiswa dapat dengan mudah menulis program. 
e. Mahasiswa mampu merencanakan solusi program.

f. Mahasiswa dapat mengamati output dari program.

g. Mahasiswa dapat memeriksa keakuratan output program.

h. Mahasiswa mudah dapat memecahkan masalah yang dihadapi saat menulis sebuah program.

i. Mahasiswa bertanya kepada dosen jika ada masalah saat menulis sebuah program.

j. Mahasiswa bertanya kepada seorang teman jika ada masalah saat menulis sebuah program.

k. Mahasiswa dapat menulis program serupa sendiri.

1. Apakah ada lagi soal kinerja mahasiswa?

\section{Analisis Data}

Untuk mengetahui apakah ada perbedaan antara pre-test dan post-test, paired samples T-test dihitung dengan data yang dikumpulkan dari Problem Solving Inventory. Data yang dikumpulkan dari masing-masing wawancara kelompok fokus pertama kali ditranskripsi dengan kata demi kata, dan kemudian proses analisis konten diterapkan. Setiap wawancara dibaca lebih dari satu kali, interpretasi dikodekan dan tabel frekuensi dibuat, tema yang muncul diidentifikasi, harmonisasi kode dan tema diperiksa. Akhirnya, item pada formulir observasi disimpulkan untuk setiap mahasiswa dan item yang paling sedikit dilakukan diidentifikasi.

\section{HASIL DAN PEMBAHASAN}

\section{Pengaruh Pengajaran Pemrogaman Animasi Melalui Aplikasi Scratch Pada Kemampuan Pemecahan Masalah}

Hasil T-test pre-test dan post-test PSI ditunjukkan pada Tabel 3. Menurut hasil ini, tidak ada perbedaan antara hasil sebelum dan pasca tes kemampuan pemecahan masalah mahasiswa [t $(48)=0,26, \mathrm{p}>0,05]$. Untuk analisis lebih detail, uji-T untuk sebelum dan pasca tes antara sub-skala juga dilakukan. Hanya ada peningkatan yang tidak signifikan dalam mean faktor "rasa percaya diri terhadap kemampuan pemecahan masalah mereka". Dengan kata lain, pemrograman di platform Scratch tidak menimbulkan perbedaan yang signifikan dalam keterampilan memecahkan masalah mahasiswa. Hasil ini mungkin menunjukkan bahwa pemrograman di platform Scratch mungkin tidak berdampak pada kemampuan pemecahan masalah.

Seperti dapat dilihat dari hasil data kuantitatif, persepsi diri mahasiswa tentang kemampuan pemecahan masalah mereka ternyata sangat rendah. Mahasiswa harus didukung dengan berbagai kegiatan yang membutuhkan pemikiran tinggi untuk membantu mereka mengembangkan keterampilan memecahkan masalah.

Tabel 3. Hasil T-Test Pre-Test dan Post-Test pada PSI

\begin{tabular}{lcccccc}
\multicolumn{1}{c}{ Test } & Mean & N & Std. Dev & df & t & p \\
\hline Pre-Test & 2.07 & 21 & 0.52 & 48 & 0.03 & 0.98 \\
Post-Test & 2.07 & 21 & 0.58 & & & \\
$\begin{array}{l}\text { Pre-Test } \\
\text { Kepercayaan }\end{array}$ & & & & & & \\
$\begin{array}{l}\text { Diri dalam } \\
\text { Kemampuan }\end{array}$ & 2.1 & 21 & 0.64 & 48 & -0.67 & 0.51 \\
$\begin{array}{l}\text { Problem } \\
\text { Solving }\end{array}$ & & & & & & \\
$\begin{array}{l}\text { Post-Test } \\
\text { Kepercayaan }\end{array}$ & & & & & & \\
$\begin{array}{l}\text { Diri dalam } \\
\text { Kemampuan }\end{array}$ & 2.17 & 21 & 0.74 & & & \\
$\begin{array}{l}\text { Problem } \\
\text { Solving }\end{array}$ & & & & & & \\
$\begin{array}{l}\text { Pre-Test } \\
\text { Kontrol Diri } \\
\text { Post-Test } \\
\text { Kontrol Diri }\end{array}$ & 2.06 & 21 & 0.68 & 48 & 1.49 & 0.14 \\
$\begin{array}{l}\text { Pre-Test } \\
\text { Pengelakan }\end{array}$ & 2.03 & 21 & 0.74 & & & \\
$\begin{array}{l}\text { Post-Test } \\
\text { Pengelakan }\end{array}$ & 2.01 & 21 & 0.7 & & & \\
\hline
\end{tabular}




\section{Pendapat Mahasiswa Tentang Pemrogaman Animasi}

Ketika mahasiswa ditanya apakah mengalami kesulitan atau tidak dalam proses pemecahan masalah, 2 mahasiswa mengatakan bahwa mereka mengalami kesulitan. Seorang mahasiswa mengatakan bahwa proyek Maze sulit ditangani. Untuk mengatasi situasi ini, 5 maahmahasiswa mengatakan bahwa mereka mendapatkan bantuan dari dosen, sementara 2 orang menjelaskan bahwa mereka mendapat pertolongan dari seorang teman. Seorang mahasiswa mengungkapkan pendapatnya sebagai "Jelas, terkadang saya mengalami kesulitan". Tetapi programnya direncanakan dengan sangat baik, artinya Anda dapat melihat di mana semuanya saat melihat-lihat program". Tidak seperti mahasiswa yang bermasalah, 6 mahasiswa mengatakan bahwa mereka tidak memiliki masalah dengan proses pemecahan masalah. 5 mahasiswa mengatakan bahwa prosesnya mudah karena mereka mengikuti instruksi dosen dengan saksama.

Ketika mahasiswa ditanyai tentang apa yang ingin mereka pelajari dari pemrograman animasi, semua mahasiswa menyatakan bahwa mereka ingin memperbaiki diri dalam pemrograman. Apalagi, 6 di antaranya menyatakan ingin membuat game 3D yang lebih besar dan lebih sulit. 2 di antaranya menyatakan bahwa mereka ingin belajar Photoshop dan dua orang lainnya ingin menulis kode program (Tabel 4). Dalam pengertian ini, seorang mahasiswa menyatakan bahwa "Kami menulis program dengan blokir dari sini, pemrogram komputer menggunakan beberapa huruf saja, karena [Scratch] menunjukkan cara mudah untuk melakukannya." dan "Saya pikir aplikasi
Scratch sangat masuk akal karena sangat bagus, menyenangkan dan mudah, ini diperuntukkan bagi kita karena rasa penasaran dengan permainan yang kita gunakan untuk anak-anak".

Tabel 4. Pendapat mahasiswa untuk rencana selanjutnya

\begin{tabular}{lr}
\hline \multicolumn{1}{c}{ Tema } & $\#$ \\
\hline Ingin meningkatkan kemampuan skill programming & 13 \\
Membuat game 3D & 6 \\
Belajar Photoshop & 2 \\
Ingin belajar menulis bahasa pemrogaman & 2 \\
\hline
\end{tabular}

\section{PENUTUP}

Dalam penelitian ini, para peneliti mengeksplorasi pengaruh pemrograman Scratch pada keterampilan pemecahan masalah mahasiswa jurusan Pendidikan Informatika di IKIP Veteran Jawa Tengah. Menurut hasil kuantitatif, pemrograman di platform Scratch tidak menyebabkan perbedaan yang signifikan dalam keterampilan memecahkan masalah mahasiswa. Hasil ini mungkin menunjukkan bahwa pemrograman di platform Scratch mungkin tidak berdampak pada kemampuan pemecahan masalah mereka. Hasil ini hanya bisa dipertimbangkan dalam lingkup penelitian ini. Hasil yang berbeda dapat dicapai dalam konteks dan desain penelitian yang berbeda. Namun, meskipun penelitian ini dilakukan dalam jangka waktu singkat dan dengan sejumlah kecil aplikasi. Ada sedikit peningkatan pada kepercayaan diri mahasiswa terhadap kemampuan pemecahan masalah mereka. Perbaikan kecil ini juga berharga untuk kondisi ini. Sebenarnya, ini menyoroti kemungkinan bahwa pemrograman dapat mempengaruhi kemampuan memecahkan masalah mahasiswa. 
Hal lain yang perlu dipertimbangkan adalah bahwa persepsi diri mahasiswa tentang kemampuan pemecahan masalah mereka ternyata sangat rendah. Mahasiswa harus didukung dengan berbagai aktivitas dan aplikasi yang memerlukan pemikiran tinggi untuk membantu mahasiswa mengembangkan keterampilan pemecahan masalah.

Ketika pemikiran utama mahasiswa dipertimbangkan, dapat dikatakan dengan jelas bahwa mahasiswa menyukai pemrograman dan ingin memperbaiki program mereka. Dalam proses pemecahan masalah, sementara setengah dari mahasiswa mengalami beberapa kesulitan, yang lainnya tidak. Kebanyakan dari mereka mencoba memecahkan masalah mereka dengan cara yang berbeda. Aspek favorit dari aplikasi ini adalah menugaskan sebuah perintah ke karakter, belajar menulis sebuah permainan, menambahkan sebuah variabel ke sebuah program, berbagi apa yang mereka lakukan dengan orang lain dan menciptakan dunia mereka sendiri. Aspek yang paling tidak disukai adalah tidak ada efek khusus yang bisa diterapkan pada karakter, penghapusan blok, kompleksitas blok panjang, tidak menemukan perintah dan karakter yang diinginkan dan karakter yang terbatas. Akhirnya, sebagian besar mahasiswa menemukan platform yang mudah digunakan.

Berdasarkan literatur dan pendapat ahli, jelaslah bahwa pemrograman animasi komputer dapat meningkatkan kemampuan pemecahan masalah peserta didik di segala usia, yang mendesak adanya kebutuhan akan pengembangan kegiatan multimedia berbasis pemrograman multimedia, terutama bagi pelajar muda. Di sisi lain, hanya menyediakan lingkungan belajar tidak akan cukup untuk memenuhi kebutuhan pengajaran yang efektif. Oleh karena itu, seperti yang dikatakan oleh (Fessakis, Gouli dan Mavroudi, 2013) "Pendekatan pembelajaran atau pembelajaran yang divalidasi secara eksperimental, praktik, terdokumentasi, sumber belajar, standar kurikulum, pengembangan profesional dan dukungan untuk guru juga dibutuhkan.

\section{REFERENSI}

Serin, 0., Bulut Serin, N., Saygrlr, G. (2010). Investigation of Gifted Students' Problem-Solving Skills. Journal for the education of Gifted Young. 9 (2), 446-458

Creswell, J.W. (2012). Educational Research: Planning, Conducting, and Evaluating Quantitative and Qualitative Research (4th Ed.). Boston: Pearson Education.

Fessakis, G., Gouli, E., Mavroudi, E. (2013). Problem solving by 5-6 years old kindergarten children in a computer programming environment: a case study. Computers \& Education, 63, 87-97.

Green, T. R. G., \& Petre, M. (1996). Usability Analysis of Visual Programming Environments: A 'Cognitive Dimensions' Framework. Journal of Visual Languages \& Computing, 7(2), 131-174.

Malan, D., \& Leitner, H. (2007). Scratch for budding computer scientists. In 38th sigcse technical symposium on computer science education (Vol. 391, pp. 223-227).

Maloney, J. H., Peppler, K., Kafai, Y., Resnick, M., \& Rusk, N.(2008). Programming by choice: Urban youth 
learning programming with Scratch. Proceedings of the 39th Technical Symposium on Computer Science Education - SIGCSE '08, 367.

Resnick, M., Kafai, Y., \& Maeda, J.(2003). A networked, media-rich programming environment to enhance technological fluency at after-school centers in economicallydisadvantaged communities. (Proposal to the National Science
Foundation, USA; project funded 2003-2007. Available at http://web.media.mit.edu/ mres/papers.html, diakses 25 Januari 2017).

Sivilotti, P. a. G., \& Laugel, S. a. (2008, February). Scratching the surface of advanced topics in software engineering. ACM SIGCSE Bulletin, 40(1), 291. 